\title{
Componentes da produção em cultivares de soja com crescimento determinado e indeterminado
}

\section{Components of the production in soybean cultivars with determinate and indeterminate growth}

\author{
Luiz Junior Perini ${ }^{1 *}$; Nelson da Silva Fonseca Júnior²; \\ Deonisio Destro ${ }^{3}$; Cássio Egidio Cavenaghi Prete ${ }^{4}$
}

\begin{abstract}
Resumo
A obtenção de cultivares de soja mais produtivas esta cada vez mais difícil, devido aos altos níveis de produtividade já alcançados para esta leguminosa. O trabalho teve como objetivo avaliar os componentes da produção de cultivares de soja de crescimento determinado e indeterminado, visando a seleção indireta para maior produtividade de grãos. Três cultivares de soja com tipo de crescimento determinado e quatro com tipo indeterminado foram avaliadas, no ano agrícola de 2009/2010. O delineamento experimental empregado foi blocos casualizados, com quatro repetições e sete tratamentos (cultivares). As características analisadas foram: altura da planta; número de nós por planta; número de vagens e grãos por planta; produtividade de grãos por planta; componentes da produtividade de grãos nos quatro últimos nós; massa de mil grãos; massa seca da planta; índice de colheita; número de ramos e vagens nos ramos. Empregou-se análise de variância em blocos ao acaso com informação dentro de parcela. As diferenças entre médias foram comparadas pelo teste de Tukey a 5\% de probabilidade. As variâncias e covariâncias fenotípicas obtidas pela ANAVA geraram a matriz de correlações fenotípicas entre caracteres. Em seguida foi realizou-se a análise de trilha. Cultivares com tipo de crescimento determinado e indeterminado não diferem quanto aos componentes de produção, diferem apenas para altura na maturidade. Porém, os critérios usados para seleção não devem ser os mesmos entre os dois tipos de cultivares. O número de vagens totais e o número de vagens nos ramos para cultivares com crescimento determinado e o índice de colheita para os indeterminados mostraram maior importância para seleção indireta de cultivares mais produtivos. Independente do tipo de crescimento, o número de grãos por planta está diretamente relacionado com a máxima produtividade em soja.
\end{abstract}

Palvras-chave: Glycine max, análise de trilha, genética, melhoramento

\begin{abstract}
The obtain more productive soybean cultivars is increasingly difficult, due to high levels of productivity has already achieved for this legume. The work had as objective to evaluate the components of the production of soybean cultivars of determinate and indeterminate growth, aiming the indirect selection for major productivity of grains. Three cultivars of soybean with type determinate of growth and four with type indeterminate were evaluated, in the agricultural year 2009/2010. The experimental design was randomized blocks with four replications and seven treatments (cultivars). The characteristics analyzed were: plant height, number of nodes per plant, number of pods and grains per plant, grain yield
\end{abstract}

\footnotetext{
${ }^{1}$ Mestre em Agronomia. Universidade Estadual de Londrina, UEL, Campus Universitário, Centro Ciências Agrárias, PósGraduação em Agronomia, PGA, C P 6001, CEP 86051-990. Londrina, PR. E-mail: luizperini50@hotmail.com

${ }^{2}$ Pesquisador, em Genética e Melhoramento, Instituo Agronômico do Parará, IAPAR, Londrina, PR. E-mail: nsfjr@iapar.br

${ }^{3}$ Prof. Dr. Aposentado, UEL, Londrina, PR. E-mail: deonisiodestro@yahoo.com

${ }^{4}$ Prof. Dr. do Dept ${ }^{\circ}$ de Agronomia,CCA/UEL, Londrina, PR. E-mail: cassio@uel.br

* Autor para correspondência
} 
per plant, grain yield components in the last four nodes; thousand grain mass, plant fresh mass; harvest index, number of branches and pods on the branches. We have used analysis of variance in randomized blocks with information within the plot. The differences among average have been compared by Tukey test at $5 \%$ probability. The phenotypic variances and covariances obtained by ANOVA generated the phenotypic matrix of correlation among traits. Following has been realized the path analysis. Cultivars with type determinate of growth and indeterminate don't differ as to the components of production, differ only for height at maturity. But the criterions used for selection should not be the same between the two types of cultivars. The number of pods total and number of pods on branches for cultivars with determinate growth and the harvest index for indeterminate showed the most importance for indirect selection of cultivars more productive. Independent of the type of growth, the number of grains per plant is directly related with the maximum productivity in soybean.

Key words: Glycine max, path analysis, genetics, breeding

\section{Introdução}

O Brasil é o segundo maior produtor mundial de soja (Glycinemax (L.) Merrill), emrazão de aumentos na produção desta cultura. $\mathrm{O}$ incremento médio $35,5 \mathrm{~kg} \mathrm{ha}^{-1} \mathrm{ano}^{-1}$ na produtividade, entre 1976/77 até $2010 / 11$, foi proporcionado principalmente pelo melhoramento genético e a expansão na área de cultivo (CONAB, 2010). Embora aumentos tenham ocorrido a cada ano, genótipos com maior produtividade de grãos serão cada vez mais difíceis de serem obtidos, exigindo mais esforços dos programas de melhoramento de soja. Carvalho et al. (2002), reforçam que a produtividade de grãos é um caráter complexo e resultante da expressão e associação de diferentes componentes.

De acordo com Pandini, Vello e Lopes (2002) o conhecimento das correlações diretas e indiretas sobre determinado componente da produção, em especial a produtividade de grãos, permite ao melhorista utilizar essas informações adicionais para descartar ou promover com maior precisão os genótipos de interesse. Pipolo, Gastaldi e Pipolo (2005) relatam que, a correlação entre caracteres possibilita a seleção indireta de um caráter quantitativo, de difícil ganho de seleção, por meio da seleção de outro caráter diretamente a ele correlacionado de maior ganho genético ou de fácil seleção visual. Segundo a teoria da genética quantitativa, causas genéticas e ambientais de correlação se combinam para produzir a correlação fenotípica (WAITT; LEVIN, 1998). Nesse contexto, a pleiotropia é a principal causa genética que explica a ocorrência de correlações, aonde duas ou mais características são influenciadas pelos mesmos genes. $\mathrm{O}$ efeito de todos os genes que afetam ambas as características resulta na correlação (RAMALHO; SANTOS; PINTO, 2004).

Entretanto, Rodrigues et al. (2010) reforça o fato de que coeficientes de correlações simples, não representam a relação exata de causa e efeito entre caracteres, que segundo Dewey e Lu (1959) pode ser enganosa se a correlação alta entre dois caracteres for consequência do efeito indireto de outras características.

A análise de trilha (path analysis) proposta por Wright (1921), permite melhor compreensão entre a associação de diferentes caracteres, por meio do desdobramento dos coeficientes de correlação, em efeitos diretos e indiretos sobre um caráter principal. Esta análise foi utilizada inicialmente em plantas por Dewey e Lu (1959); mais tarde foi empregada em outras culturas, como a soja tendo seu uso reportado por Carvalho et al. (2002), Board, Kang e Bodrero (2003) e Bizeti et al. (2004). Embora a análise tenha sido amplamente utilizada, não existem estudos associando a produtividade de grãos com diferentes tipos de crescimento e localização das vagens na planta de soja, que é determinada pelo tipo de crescimento. Conforme Bernard (1972), dois locos gênicos controlam o tipo de crescimento em soja (Dt1/dt1) e (Dt2/dt2). Nogueira et al. (2009) classifica os genótipos indeterminados (Dt1 Dt1 dt2 dt2), como plantas que possuem apenas inflorescência axilar, sendo que nestas a gema 
apical mantêm o crescimento vegetativo após inicio do florescimento. Os Determinados (dt1 dt1 - -) possuem inflorescência racemosa terminal e axilar, o crescimento vegetativo quase cessa após o florescimento, podendo crescer até $10 \%$ da altura final. Semideterminados (Dt1 Dt1 Dt2 - ou Dt1 dt1 - - ) possuem inflorescência racemosa terminal e axilar, atingindo $70 \%$ da altura final ao florescer.

Kiihl em comunicação pessoal, apud Harada (2006), relata que o tipo de crescimento determinado predominante nas cultivares de soja brasileira é uma das limitações para o aumento da produtividade de grãos. Entretanto, nos últimos anos o cultivo de cultivares de soja indeterminadas tem aumentado significativamente.

O trabalho teve como objetivo avaliar os componentes da produção de cultivares de soja de crescimento determinado e indeterminado, visando a seleção indireta para maior produtividade de grãos.

\section{Material e Métodos}

A condução do trabalho foi realizada na fazenda escola da Universidade Estadual de Londrina (UEL), localizada no município de Londrina, Paraná, cujas coordenadas geográficas são: $23^{\circ} 20^{\prime} 25^{\prime}$ 'S e $51^{\circ} 12^{\prime} 36^{\prime}$ 'O, com altitude média de 540 metros. Foram avaliadas sete cultivares de soja com diferentes tipos de crescimento (Tabela 1), sendo três cultivares de crescimento determinado e quatro cultivares de crescimento indeterminado, provenientes do Centro Nacional de Pesquisa de Soja (Embrapa Soja), Cooperativa Central de Pesquisa Agrícola (Coodetec), Syngenta Seeds (NK), Brasmax (BMX).

Tabela 1. Nome, tipo de crescimento, ciclo e grupo de maturação das cultivares de soja utilizadas no trabalho. UEL, Londrina, Ano agrícola de 2009/2010.

\begin{tabular}{lccc}
\hline Tratamentos (cultivares) & Tipo de crescimento & Ciclo & Grupo de maturação \\
\hline CD 206 & Determinado & Semiprecoce & 6.8 \\
BRS 282 & Determinado & Semiprecoce & 6.9 \\
BRS 246 RR & Determinado & Médio & 7.2 \\
\hline BMX Potência RR & Indeterminado & Semiprecoce & 6.6 \\
NK 7059 RR & Indeterminado & Superprecoce & 5.9 \\
BRS 284 & Indeterminado & Precoce & 6.3 \\
BMX Titan RR & Indeterminado & Superprecoce & 5.3 \\
\hline
\end{tabular}

(1) CD - Cooperativa Central de Pesquisa Agrícola (Coodetec); BRS - Centro Nacional de Pesquisa de Soja (Embrapa Soja); NK Syngenta Seeds; BMX - Brasmax.

Fonte: Elaboração dos autores.

O delineamento experimental empregado no campo foiblocos casualizados, com quatro repetições e sete tratamentos (cultivares). O espaçamento entre linhas foi de $45 \mathrm{~cm}$, com quatro linhas de cinco metros por parcela e, estande final de 10 plantas por metro linear. A semeadura foi realizada em 30 de outubro de 2009, em área sob sistema de plantio direto. Pela interpretação da análise de solo, simultaneamente com a semeadura, aplicou- se na linha $200 \mathrm{~kg} \mathrm{ha}^{-1}$ do fertilizante composto por fósforo e potássio (PK), fórmula 00-20-20. O controle de plantas daninhas, manejo de pragas e doenças seguiram as recomendações técnicas da Embrapa Soja para o Paraná (TECNOLOGIAS DE PRODUÇÃO DE SOJA - PARANÁ, 2006).

Ao atingir o ponto de colheita R8 (FEHR; CAVINESS, 1977), foram colhidas aleatoriamente vinte plantas de cada parcela nas duas linhas 
centrais, excluindo-se um metro de cada linha como bordadura. Determinaram-se individualmente as seguintes características agronômicas: altura de planta, distância a partir da superfície do solo até a última vagem na haste principal da planta (AP em $\mathrm{cm}) ; \mathrm{n}^{\mathrm{o}}$ de nós na haste (NNH: determinado a partir do primeiro nó verdadeiro); massa seca da planta (MSP em g); índice de colheita (IC: massa de grãos por planta/massa seca da planta; massa de mil grãos (MMG em g); $\mathrm{n}^{\circ}$ de grãos por planta (NGP); massa de grãos por planta (MGP em g); $\mathrm{n}^{\circ}$ de vagens total (NVT); $\mathrm{n}^{0}$ de vagens da haste nos quatro últimos nós superiores (NV4UN); $\mathrm{n}^{0}$ de grãos nos quatro últimos nós superiores (NG4UN); massa de grãos nos quatro últimos nós superiores (MG4UN em g); $\mathrm{n}^{\mathrm{o}}$ de ramos (NR) e $\mathrm{n}^{\mathrm{o}}$ vagens nos ramos (NVR: foram considerados ramos todas as estruturas com pelo menos dois nós). A escala de Fehr e Caviness (1977) foi utilizada como parâmetro, para estratificação da planta de soja, levando em conta os quatro últimos nós superiores na haste.

Realizou-se análise de variância em blocos ao acaso com informação dentro de parcela. As diferenças entre médias foram comparadas pelo teste de Tukey a 5\% de probabilidade. As variâncias e covariâncias fenotípicas obtidas pela ANAVA geraram a matriz de correlações fenotípicas entre caracteres. Inicialmente foi realizada a análise de trilha com um único diagrama causal, ou seja, a variável principal (produtividade de grãos por planta) em função de dois componentes primários (massa de mil grãos e o número de grãos por planta). Em seguida, realizou-se a análise de trilha considerando-se dois diagramas causais, ou seja, variável principal em função dos componentes primários e estes em função de componentes secundários. Todas as análises estatísticas foram realizadas pelo programa Genes versão 2009 (CRUZ, 2001). As características MFP, NVT, NVR, NGP, MGP, MMG, NV4UN, NG4UN, MG4UN e IC foram transformadas para a escala logarítmica devido à existência de inter-relação entre elas, em razão do efeito multiplicativo.

\section{Resultados e Discussão}

De acordo com a análise de variância (Tabela 2), todas as características avaliadas apresentaram diferença significativa ao nível de $1 \%$ de probabilidade em função de cultivares.

Para o caráter AP, os cultivares indeterminados apresentaram altura maior do que os cultivares determinados (tabela 3). Pode se inferir que a altura de planta está relacionada com o tipo de crescimento. Os cultivares indeterminados Potência, NK 7059 RR e BRS 284, apresentaram maior número de nós na haste que os cultivares determinados, porém o cultivar indeterminado Titan RR não diferiu do cultivar BRS 246 RR para número de nós na haste. Segundo Carvalho et al. (2002) o número de nós na haste principal tem influência variável na produtividade de soja.

O cultivar CD 206 apresentou massa seca da planta maior que o dos cultivares NK 7059 RR e Titan RR. Já nos demais casos não foi possível observar diferenças. Os cultivares BRS 246 RR e BRS 284 apresentaram índice de colheita maior do que o cultivar CD 206. O índice de colheita não se mostrou associado ao tipo de crescimento e nem com a massa seca da planta. Nem sempre as plantas com a maior massa seca serão as mais produtivas, pois o índice de colheita leva em consideração a massa das sementes em relação à massa seca da planta.

Os cultivares CD 206, BRS 246 RR, NK 7059 RR e Titan RR, apresentaram massa de mil sementes maior que a dos cultivares BRS 284, Potência RR e BRS 282. Esta característica não apresentou relação com o tipo de crescimento. Para número de grãos por planta os cultivares BRS 282, Potência e BRS 284 apresentaram valores maiores em relação aos cultivares NK 7059 RR e Titan RR. Esse resultado demonstra que quanto maior a massa de mil sementes menor será o número de grãos por planta. 
Tabela 2. Análise de variância de treze características de importância agronômica, avaliadas em sete cultivares de soja com diferentes tipos de crescimento.

\begin{tabular}{lccccccc}
\hline \multirow{2}{*}{ Fonte de variação } & \multicolumn{7}{c}{ Quadrado médio } \\
\cline { 2 - 7 } & $\mathrm{AP}^{(1)}$ & $\mathrm{NNH}$ & $\mathrm{MSP}$ & $\mathrm{IC}$ & MMG & NGP & MGP \\
\hline Variedades & $24094,89^{* *}$ & $259,43^{* *}$ & $1018,27^{* *}$ & $0,14^{* *}$ & $34437,30^{* *}$ & $24753,29^{* *}$ & $254,58^{* *}$ \\
Resíduos & 132,60 & 5,88 & 305,44 & 0,01 & 937,91 & 2602,72 & 77,64 \\
Médias & 87,11 & 14,35 & 32,75 & 0,46 & 169,25 & 90,97 & 15,66 \\
C.V.(\%) & 13,22 & 16,91 & 53,35 & 29,06 & 18,09 & 56,08 & 56,25 \\
\hline \multirow{7}{*}{ Fonte de variação } & NVT & NV4UN & NG4UN & MG4UN & NR & NVR \\
\cline { 2 - 7 } Variedades & $5377,23^{* *}$ & $763,07^{* *}$ & $3555,89^{* *}$ & $194,64^{* *}$ & $55,77^{* *}$ & $2844,97^{* *}$ \\
Resíduos & 485,91 & 32,28 & 191,65 & 6,25 & 2,29 & 181,59 \\
Médias & 40,56 & 9,95 & 23,10 & 4,11 & 1,81 & 9,86 \\
C.V.(\%) & 54,34 & 57,10 & 59,91 & 60,85 & 83,68 & 136,66 \\
\hline
\end{tabular}

** e * indica significância a 1 e $5 \%$ de probabilidade, pelo teste $\mathrm{F}$.

(1) AP - altura planta; NNH - número de nós na haste; MSP - massa seca da planta; IC - índice de colheita; MMG - massa de mil grãos; NGP - número de grãos planta; MGP - massa de grãos planta; NVT - número de vagens totais; NV4UN - número de vagens nos quatro últimos nós; NG4UN - número de grãos nos quatro últimos nós; MG4UN - massa de grãos nos quatro últimos nós; $\mathrm{NR}$ - número de ramos; NVR - número de vagens nos ramos.

Fonte: Elaboração dos autores.

O cultivar BRS 246 RR apresentou massa de grão por planta maior em relação aos cultivares NK 7059 RR e Titan RR, nos demais casos não há diferença. Para o caracter número de vagens totais, os cultivares BRS 282, BRS 246 RR e BRS 284 diferem dos cultivares CD 206, NK 7059 RR, e Titan RR. Os cultivares BRS 246 e BRS 284, apresentaram número de vagens nos 4 últimos nós maior do que os cultivares BRS 282, Potência RR, NK 7059 RR Titan RR. Os maiores números de grãos nos 4 últimos nós foram observados nos cultivares CD 206, BRS 246 RR e BRS 284. O cultivar CD 206 juntamente com o BRS 246 RR apresentaram massa de grãos nos quatro últimos nós, maior que nos demais cultivares. Para Bárbaro et al. (2006) o caráter número de vagens por planta é um dos mais importantes sobre a produtividade de grãos.
O maior número de ramos foi observado no cultivar BRS 282. Os cultivares CD 206, BRS 246 RR, Potência RR e Titan RR apresentaram maior número de ramos em relação aos cultivares NK 7059 RR e BRS 284. Para número de vagens nos ramos o cultivar BRS 282 e BRS 246 RR, diferem dos demais tratamentos. O número de ramos e número de vagens nos ramos não revelou associação com tipo de crescimento.

Esses resultados demonstram que os componentes de rendimento não estão associados com o tipo de crescimento. Portanto a obtenção de cultivares com altas produtividades não depende do tipo de crescimento. Para as características morfológicas analisadas, os cultivares com crescimento determinado, diferem dos de crescimento determinado, apenas para altura de planta. 


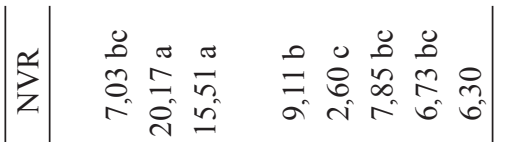

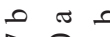

요 त)

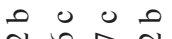

ते 0 ने

ส

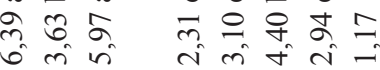

$\pi$ ת

क

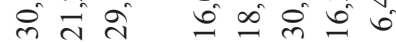

ส

Fे

之

कर

ค

元

б.

ले भे के के ती

สิ สิ

든

드은

สิ

光

:

ํํำ

त 0 त 0

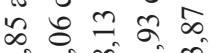

을 $\infty$

*

a to

芒宁

- $\pi 0 \pi$

ㅇ $\approx$ กิ

in $\infty \infty^{\infty}$

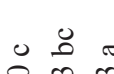

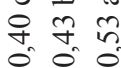

:

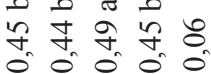

芯

है

过

ป

.

कृ

$\sum^{-1}$

일

要

Оิ

Z

ᄋ్త్ర

का है

छू

\%

정

芚

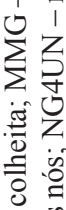

\%

导 是

$\exists \stackrel{0}{\Xi}$

U च छ

क्ष

츨 की

$\pi$ (⿻)

త్ర

क $>0$

范

当记离

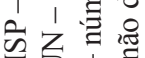

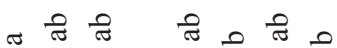

ल ํำ

$\infty \sqrt[n]{n} \approx n$

से ते तै ते

\& 0.0

$\infty$ o ?

तै

ก $\pi$ n

ป

ติ

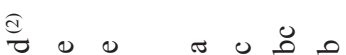

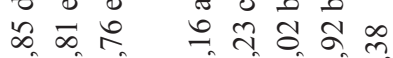

i

है ๙ે

중 줌

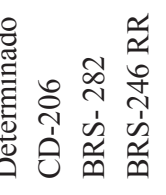

De acordo com a Tabela 4, algumas características apresentaram correlações fenotípicas maiores que 0,9 em módulo, com a variável principal, massa de grãos por planta. Para cultivares com tipo de crescimento determinado a massa de mil grãos, o IC, o número de grãos por planta e o NV4UN apresentaram alta correlação com massa de grãos por planta. Nos cultivares com crescimento indeterminado houve alta correlação para $\mathrm{NNH}$, MSP, número de grãos por planta e NVT com a variável principal massa de grãos por planta. Para a variável primária massa de mil grãos, em cultivares determinados, a maior correlação foi entre $\mathrm{NNH}$, massa de grãos por planta, NV4UN, NG4UN e MG4UN, enquanto que para os indeterminados, a massa de mil grãos mostrou correlação negativa com todos os caracteres avaliados. A variável primária número de grãos por planta teve alta correlação com IC e massa de grãs por planta em cultivares determinados. Para os indeterminados, a maior correlação encontrada com número de grãos planta foi para NNH, MSP e NVT. Segundo Arshad; Ali e Ghafoor (2006) as características número de vagens por planta e massa de mil grãos, devem receber maior ênfase na seleção de linhagens de soja com alto rendimento. 


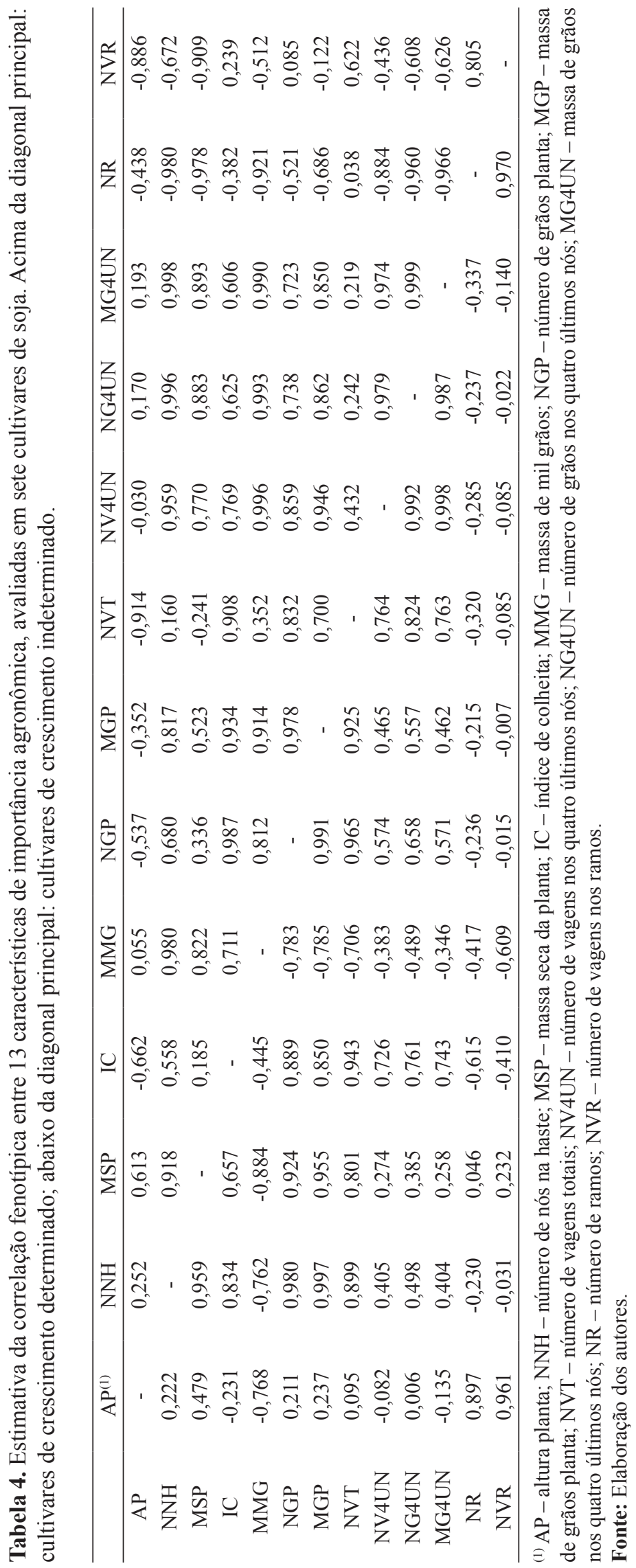


Para reunir em um só cultivar, maior massa de grãos por planta, número de grãos por planta e massa de mil grãos (Tabela 4), empregou-se a análise de trilha proposta por Wright (1921), que é uma ferramenta estratégica para a superação das dificuldades encontradas pelos melhoristas de planta. Ao priorizar algumas características de maior importância (maior grau de associação) obtêm-se maiores produtividades de grãos em menor tempo.

Ao realizar a análise de trilha com um único diagrama casual (Tabela 5), verificou-se que a massa de mil grãos teve correlação baixa via efeito direto sobre massa de grãos por planta para os dois grupos de cultivares de soja estudados. A correlação da massa de mil grãos por meio do efeito indireto via número de grãos por planta foi alta e negativa, somente para o tipo indeterminado. À medida que o número de grãos aumenta a massa individual diminui. Os resultados de Bizeti et al. (2004), demonstram que a soja pode aumentar ou diminuir o número de sementes em função de seu tamanho como uma espécie de efeito tampão, sem variação significativa na produtividade de grãos.

Tabela 5. Estimativa dos efeitos diretos e indiretos das variáveis primárias (massa de mil grãos e número de grãos planta) sobre a variável principal produtividade de grãos por planta (massa de grãos por planta), em cultivares de soja com tipo de crescimento determinado e indeterminado.

\begin{tabular}{|c|c|c|}
\hline Efeito & \multicolumn{2}{|c|}{ Estimativa } \\
\hline & eterminado & Indeterminado \\
\hline \multicolumn{3}{|c|}{ Massa de mil grãos } \\
\hline $\begin{array}{l}\text { Direto sobre a produtividade de grãos por planta (massa } \\
\text { de grãos planta) }\end{array}$ & 0,353 & $-0,020$ \\
\hline Indireto via número de grãos por planta & 0,561 & $-0,764$ \\
\hline Total & 0,914 & $-0,785$ \\
\hline \multicolumn{3}{|c|}{ Número de grãos por planta } \\
\hline $\begin{array}{l}\text { Direto sobre a produtividade de grãos por planta (massa } \\
\text { de grãos planta) }\end{array}$ & 0,691 & 0,975 \\
\hline Indireto via massa de mil grãos & 0,286 & 0,015 \\
\hline Total & 0,978 & 0,991 \\
\hline $\mathrm{R}^{2(1)}$ & 0,999 & 0,983 \\
\hline Efeito residual & 0,003 & 0,127 \\
\hline
\end{tabular}

${ }^{(1)} \mathrm{R}^{2}$, coeficiente de determinação do modelo de trilha com um único diagrama casual.

Fonte: Elaboração dos autores.

No entanto, a variável primária número de grãos por planta apresentou correlação alta e efeito direto positivo sobre a massa de grãos por planta, para os cultivares determinados e indeterminados. Pipolo, Gastaldi e Pipolo (2005) ao trabalhar com correlação simples, concluíram que plantas que apresentaram maior número de vagens com dois grãos apresentaram maior número de vagens por planta e, consequentemente, maior massa de grãos por planta. Porém, esses autores não relacionaram, maior número de grãos por planta com aumento na variável primária massa de grãos por planta.

Para cultivares determinados, o caráter que apresentou maior importância para seleção indireta foi NVT e NVR (Tabela 6), sobre massa de mil grãos e número de grãos por planta, via indireta altura de planta. Pandini, Vello e Lopes (2002) também relacionam que o caráter número de vagens por planta tem potencial para a seleção indireta de cultivares mais produtivos. Os mesmos resultados 
são reportados por Board, Kang e Bodrero (2003), ao concluírem que o número de sementes $\mathrm{m}^{-2}$ ou de vagens $\mathrm{m}^{-2}$ podem ser usados como critério de seleção indireta para obtenção de cultivares de alta produtividade de grãos, sendo que o autor ressalta que o número de sementes $\mathrm{m}^{-2}$ é mais preciso, mas a determinação também é mais demorada.

Nenhuma variável secundária apresentou correlação alta com a variável principal massa de grãos planta. As variáveis secundárias NNH, MSP, NV4UN e MG4UN tiveram correlação indireta via NG4UN, sobre a variável primaria massa de mil grãos, entretanto, o número de ramos correlacionouse negativamente via NG4UN, ou seja, à medida que se aumenta os componentes nos últimos nós ocorre a diminuição do número de ramos. A característica NG4UN apresentou correlação direta sobre a massa de mil grãos, portanto a massa unitária de grãos é maior no ápice de cultivares determinados quando comparado com cultivares indeterminados. Esse resultado, de acordo com Taiz e Zeiger (2004), é explicado pelo fato das folhas superiores interceptarem maior quantidade da radiação solar incidente, o que resulta em uma taxa fotossintética muito maior, sendo assim as vagens do ápice recebe maiores quantidades de fotoassimilados apresentando maiores massa de grãos.
Ainda para cultivares determinados, a altura de plantas apresentou correlação direta e negativa com massa de mil grãos e número de grãos por planta. Porém, a associação da altura via indireta sobre a variável secundaria NVT, apresentou correlação positiva sobre as duas variáveis primárias massa de mil grãos e número de grãos por planta, $0.672 \mathrm{e}$ 0.655 , respectivamente.

Em cultivares indeterminados, a variável secundaria IC apresentou efeito direto e alto sobre a massa de grãos por planta e o número de grãos por planta (Tabela 7). As variáveis secundárias NNH, MFP, NVT, NV4UN, NG4UN e MG4UN apresentaram correlação positiva entre massa de grãos por planta e número de grãos por planta, mas todas as variantes citadas anteriormente via IC se correlacionaram negativamente com o massa de mil grãos. Esse efeito negativo reforça o fato de que à medida que há aumento no número de grãos por planta, a massa individual destes diminui. $\mathrm{O}$ índice de colheita pode ser usado como parâmetro para seleção de cultivares com tipo de crescimento indeterminado, visando maior produtividade. 


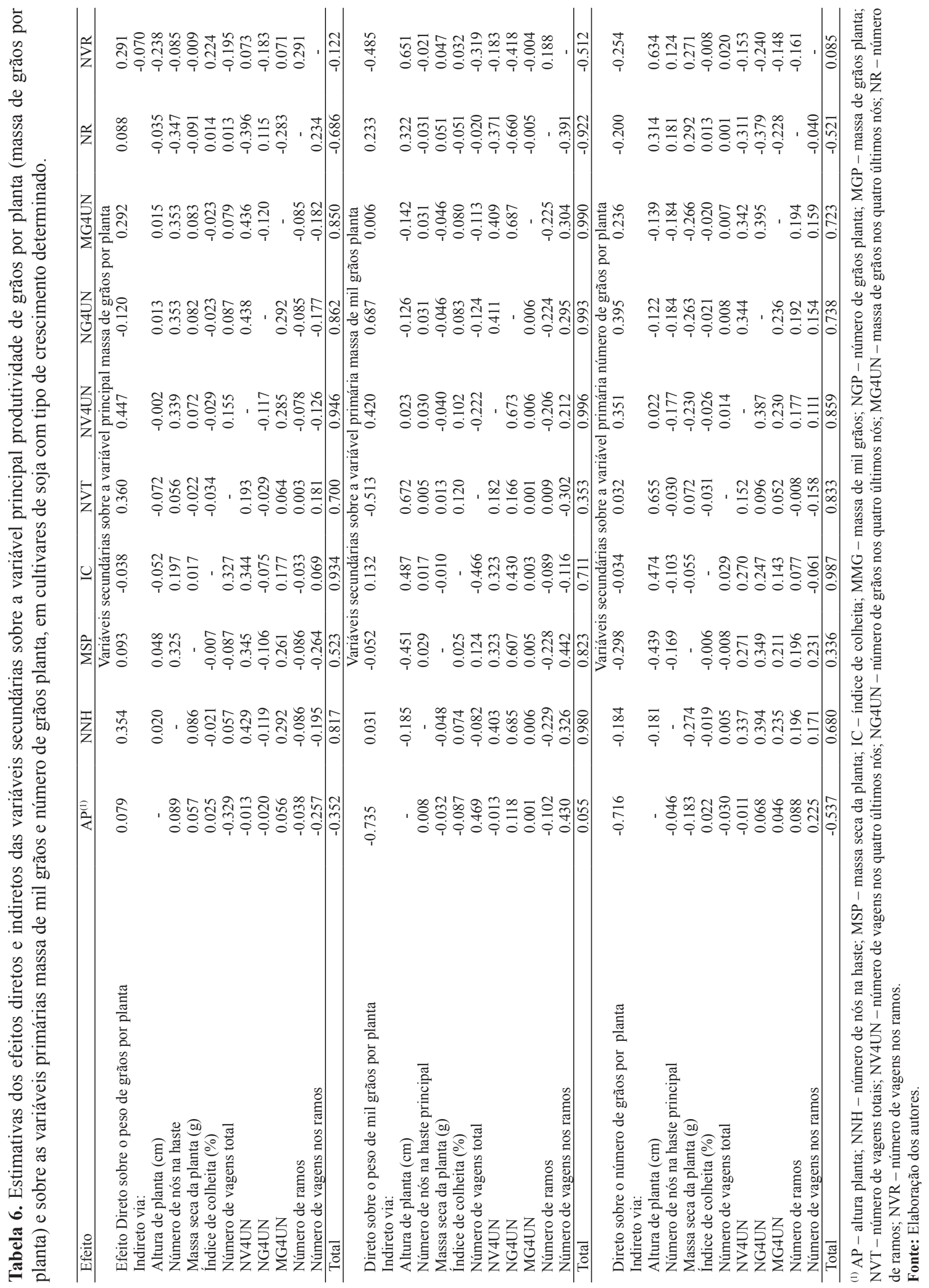




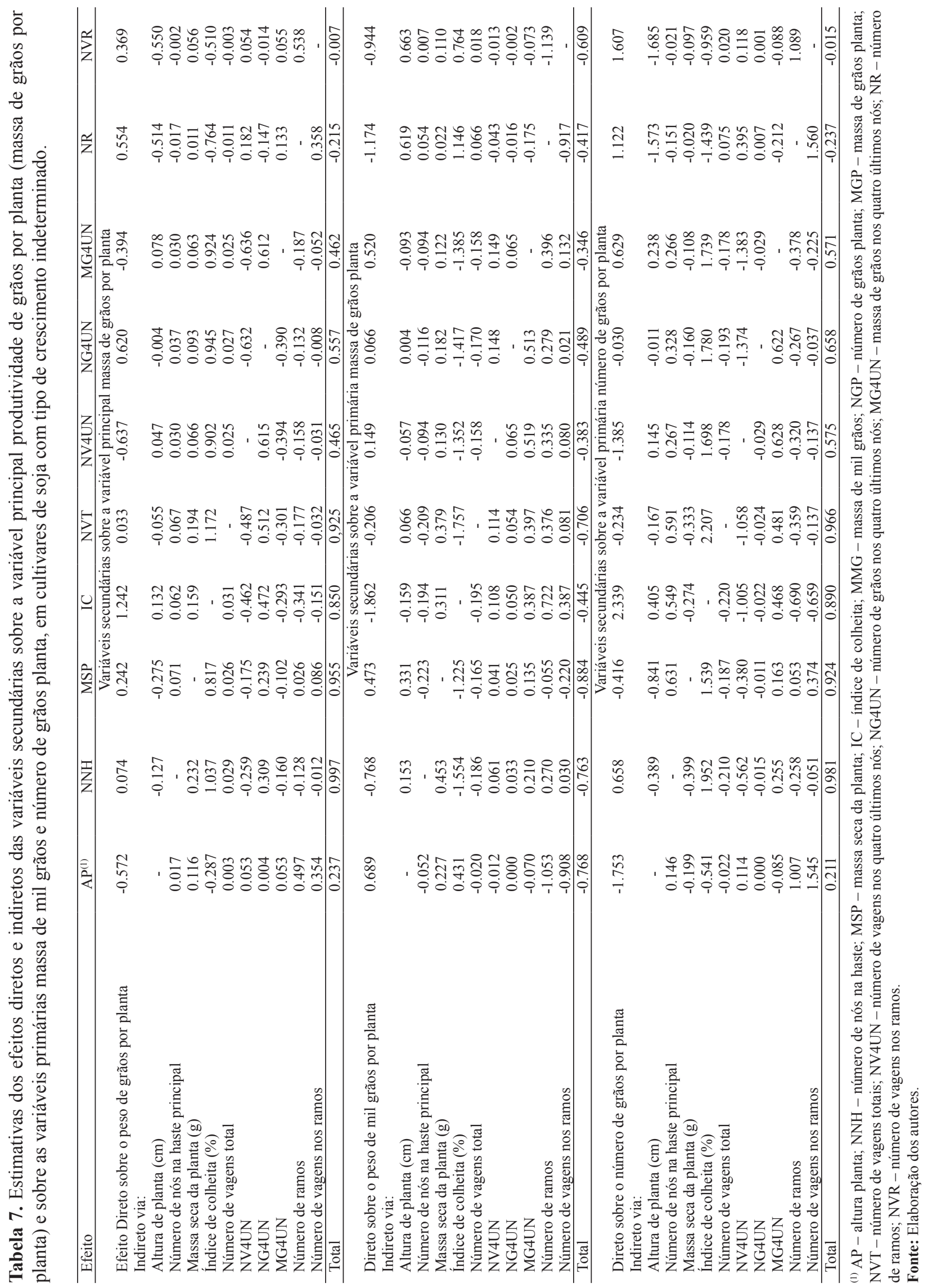




\section{Conclusões}

Cultivares com tipo de crescimento determinado e indeterminado não apresentam diferenças quanto aos componentes de produção, diferem apenas para altura na maturidade. Os critérios usados para seleção não devem ser os mesmos entre os dois tipos de cultivares.

Para cultivares determinados, o número de vagens totais, número de vagens nos ramos e massa de mil grãos, mostraram maior importância para seleção indireta de cultivares mais produtivas.

O índice de colheita pode ser usado como parâmetro para seleção indireta de cultivares com tipo de crescimento indeterminado mais produtivos.

Independente do tipo de crescimento, o número de grãos por planta está diretamente relacionado com a máxima produtividade em soja.

\section{Agradecimentos}

Ao Conselho Nacional de Desenvolvimento Científico e Tecnológico, pela concessão de bolsa e pelo apoio financeiro. Aos acadêmicos Paulo Sergio Novais e Henrique Duarte Matheus pela ajuda nas avaliações.

\section{Referências}

ARSHAD, M.; ALI, N.; GHAFOOR, A. character correlation and path coefficient in soybean Glycine max (L.) Merrill. Pakistan Journal of Botany, Pakistan, v. 38, n. 1, p. 121-130, 2006.

BÁRBARO, I. M.; CENTURION, M. A. P. C.; DI MAURO, A. O.; UNÊDA-TREVISOLI, S. H.; ARRIEL, N. H. C.; COSTA, M. M. Path analysis and expected response in indirect selection for grain yield in soybean. Crop Breeding and Applied Biotechnology, Viçosa, v. 6, n. 2, p. 151-159, 2006.

BERNARD, R. L. Two genes affecting stem termination in soybeans. Crop Science, Madison, v. 12, n. 2, p. 235239, 1972.
BIZETI, H. S.; CARVALHO, C. G. P.; SOUZA, J. R. P.; DESTRO, D. Path analysis under multicollinearity in soybean. Brazilian Archives of Biology and Technology, Curitiba, v. 47, n. 5, p. 669-676, 2004.

BOARD, J. E.; KANG, M. S.; BODRERO, M. L. Yield Components as indirect selection criteria for late-planted soybean cultivars. Agronomy Journal, Madison, v. 95, n. 2, p. 420-429, 2003.

CARVALHO, C. G. P.; ARIAS, C. A. A.; TOLEDO, J. F. F.; OLIVEIRA, M. F.; VELLO, N. A. Correlação e análise de trilha em linhagens de soja semeadas em diferentes épocas. Pesquisa Agropecuária Brasileira, Brasília, v. 37, n. 3, p. 311-320, 2002.

COMPANHIA NACIONAL DE ABASTECIMENTO - CONAB. Série histórica: soja. 2010. Disponível em: $<$ http://www.conab.gov.br/conabweb/download/safra/ SojaSerieHist.xls>. Acesso em: 18 maio 2010.

CRUZ, C. D. Programa GENES: versão windows; aplicativo computacional em genética e estatística. Viçosa: UFV, 2001. 442 p.

DEWEY, D. R.; LU, K. H. A correlation and path coefficient analysis of components of crested wheatgrass seed production. Agronomy Journal, Madison, v. 51, n. 9, p. 515-518, 1959.

FEHR, W. R.; CAVINESS, C. E. Stages of soybean development. Ames: Iowa State University of Science and Technology, 1977. 12 p. (Special Report, 80).

HARADA, A. Florescimento e período juvenil longo em soja como fator de adaptação da cultura às regiões de baixas latitudes. 2006. Tese (Doutorado em Agronomia) - Universidade Estadual de Londrina, Londrina.

NOGUEIRA, A. P. O.; SEDIYAMA, T.; BARROS, B. H.; TEIXEIRA, R. C. Morfologia, crescimento e desenvolvimento. In: SEDIYAMA, T. (Ed.). Tecnologias de produção e usos da soja. Londrina: Mecenas, 2009. p. 7-16.

PANDINI, F.; VELLO, N. A.; LOPES, A. C. A. Heterosis in soybeans for seed yield components and associated traits. Brazilian Archives of Biology and Technology, Curitiba, v. 45, n. 4, p. 401-412, 2002.

PIPOLO, V. C.; GASTALDI, L. F.; PIPOLO, A. E. Correlações fenotípicas entre caracteres quantitativos em soja. Semina: Ciências Agrárias, Londrina, v. 26, n. 1, p. 11-16, 2005.

RAMALHO, M. A. P.; SANTOS, J. B.; PINTO, C. A. B. P. Genética na agropecuária. 3. ed. rev. Lavras: UFLA, 2004. $472 \mathrm{p}$. 
RODRIGUES, G. B.; MARIM, B. G.; SILVA, D. J. H.; MATTEDI, A. P.; ALMEIDA, V. S. Análise de trilha de componentes de produção primários e secundários em tomateiro do grupo Salada. Pesquisa Agropecuária Brasileira, Brasília, v. 45, n. 2, p. 155-162, 2010.

TAIZ, L.; ZEIGER, E. Fisiologia vegetal. Tradução Santarém et al. 3. ed. Porto Alegre: Artmed, 2004. 720 p.
TECNOLOGIAS DE PRODUÇÃO DE SOJA PARANÁ. Londrina: Embrapa Soja, 2006. 217 p.

WAITT, D. E.; LEVIN, D. A. Genetic and phenotypic correlations in plants: a botanical test of Cheverud's conjecture. Heredity, v. 80, p. 310-319, 1998.

WRIGHT, S. Correlation and causation. Journal of Agricultural Research, Washington, v. 20, p. 557-585, 1921. 
